\title{
RESEARCH IN SPORT \\ PHYSICAI A TIN \\ A comparative study of physical activity and the innate immune response between young and aged university students
}

Autor(es): $\quad$ Marín, J; Martín-Cordero, L; Gálvez, I; Hinchado, MD; Ortega, E

Publicado por: Imprensa da Universidade de Coimbra

URL persistente:

URI:http://hdl.handle.net/10316.2/44163

DOI:

DOI:https://doi.org/10.14195/2182-7087_ex2018_100

Accessed : $\quad$ 26-Apr-2023 01:12:27

A navegação consulta e descarregamento dos títulos inseridos nas Bibliotecas Digitais UC Digitalis, UC Pombalina e UC Impactum, pressupõem a aceitação plena e sem reservas dos Termos e Condições de Uso destas Bibliotecas Digitais, disponíveis em https://digitalis.uc.pt/pt-pt/termos.

Conforme exposto nos referidos Termos e Condições de Uso, o descarregamento de títulos de acesso restrito requer uma licença válida de autorização devendo o utilizador aceder ao(s) documento(s) a partir de um endereço de IP da instituição detentora da supramencionada licença.

Ao utilizador é apenas permitido o descarregamento para uso pessoal, pelo que o emprego do(s) título(s) descarregado(s) para outro fim, designadamente comercial, carece de autorização do respetivo autor ou editor da obra.

Na medida em que todas as obras da UC Digitalis se encontram protegidas pelo Código do Direito de Autor e Direitos Conexos e demais legislação aplicável, toda a cópia, parcial ou total, deste documento, nos casos em que é legalmente admitida, deverá conter ou fazer-se acompanhar por este aviso. 


\section{ANNALS OF RESEARCH IN SPORT AND PHYSICAL ACTIVITY}




\section{A COMPARATIVE STUDY OF PHYSICAL ACTIVITY AND THE INNATE IMMUNE RESPONSE BETWEEN YOUNG AND AGED UNIVERSITY STUDENTS}

Marín J1; Martín-Cordero L²; Gálvez I; Hinchado MD³; Ortega E

KEYWORDS: Aging, sedentary lifestyle, phagocytic process, stress

The base of the functional longevity of each individual is health maintenance. This depends mainly on the lifestyle and environmental factors, thus it is possible to retard the rate of ageing through the modulation of these factors. Lifestyle is affected by factors such as eating habits, toxic habits, sleep patterns or physical activity. It has been demonstrated that the competence of the immune system is an excellent marker of health, and habitual exercise is an important approach to improve the immune system, especially in old people ${ }^{(1)}$. Thus, the aim of this investigation was to evaluate the daily physical activity performed by old and young university students, together with their immune and neuroendocrine response. 8 healthy young university students (University of Extremadura) from 19 to 26 years in age were compared with 8 healthy elderly university students (Elderly People's University of the University of Extremadura) from 63 to 71 years in age. Anthropometric measurements (body mass index and waist-hip ratio) were taken using standardized methods. Physical activity and the Metabolic Equivalent of Task (MET) were measured using accelerometers (ActiGraph wGT3X-BT) for 4 days. Fasting plasma glucose levels were determined using blood glucose strips, and cortisol serum levels were measured by ELISA. Chemotaxis of isolated neutrophils from peripheral blood was evaluated using a Boyden chamber. The phagocytic and microbicide capacities of monocytes and granulocyteswere evaluated in whole blood by flow cytometry.

The aged volunteers presented a higher body mass index, waist-hip ratio, and glucose values; but no differences in cortisol levels were found. Surprisingly, the elderly group per-

\footnotetext{
1 Department of Analytical Chemistry, Faculty of Sciences, University of Extremadura, Spain.

2 Immunophysiology Research Group, Department of Nursing, University of Extremadura, Spain.

${ }^{3}$ Immunophysiology Research Group, Department of Physiology, University of Extremadura, Spain.

Email: orincon@unex.es; leticiamartin@unex.es; igalvez@unex.es
} 
formed higher daily physical activity levels: more minutes of moderate-to-vigorous physical activity, more steps, and greater MET values than the younger group. Moreover, they showed a better neutrophils' chemotaxis capacity and a better monocytes' microbicide capacity than the young students; thus indicating that the elderly students did not present an innate immunosenescence status. These results may reflect worrying high levels of physical inactivity in young people. In addition, this may contribute to decrease the immune system's defenses against pathogens, and also to compromise health maintenance and favour the onset of sedentary lifestyle-related pathologies in the future.

This investigation has been supported by Junta de Extremadura-FEDER (GR-15041). We would like to thank the volunteers and the STAB (UEx) for technical and human support.

\section{REFERENCES}

1. De la Fuente, M., Cruces, J., Hernández, O. \& Ortega, E. (2011). Strategies to improve the functions and redox state of the immune system in aged subjects. Current Pharmaceutical Design. 17: 3966-3993. 